Available online at http://www.anpad.org.br/bar

BAR, Curitiba, v. 8, n. 2, art. 3, pp. 150-167, Apr./June 2011

\title{
"Why Caipirinha?"- The Online via Chat Laddering Technique CAN Answer
}

\author{
Bruno Bordeaux-Rego * \\ E-mail address: bruno_bordeaux@yahoo.com.br \\ Universidade Federal do Rio Grande do Sul \\ São Paulo, SP, Brazil. \\ Fernanda Nedwed-Machado \\ E-mail address: fernanda.nedwed@terra.com.br \\ Universidade Federal do Rio Grande do Sul \\ Porto Alegre, RS, Brazil.
}

Marta Olivia Rovedder de Oliveira

E-mail address: mrovedder@yahoo.com.br Universidade Federal do Rio Grande do Sul and UNIPAMPA

Porto Alegre, RS, Brazil.

Denise Avancini Alves

E-mail address: deniseavancinialves@yahoo.com.br Universidade Federal do Rio Grande do Sul and PUC/RS

Porto Alegre, RS, Brazil.

Luiz Antonio Slongo E-mail address: laslongo@ea.ufrgs.br Universidade Federal do Rio Grande do Sul and PUC/RS Porto Alegre, RS, Brazil.

* Corresponding author: Bruno Bordeaux-Rego

Rua Nilo, 23/ 83, Aclimação, São Paulo, SP, 01533-010, Brazil.

Copyright (C) 2011 Brazilian Administration Review. All rights reserved, including rights for translation. Parts of this work may be quoted without prior knowledge on the condition that the source is identified. 


\begin{abstract}
As customers are becoming increasingly connected to the internet, this means that they are available for online interviews, thus opening up a space for investigating research methods, especially qualitative research, in an attempt to identify how to adapt data collecting instruments to the so-called "connected customer era". In this context, the focus of this article is on the application viability analysis of the laddering technique used online and in real-time chat by asking the following question: "Why caipirinha?". Conducting online in-depth interviews through the MSN Messenger and Skype (the most commonly used chat tools in Brazil), 23 attributes, 22 consequences and 13 values were identified, resulting in 133 ladders, 71 of which reached the value level. Along with friends/mates, Integration, Entertainment and Fun, in addition to Alcohol, Insouciance/ relaxation and Pleasure constitute the most frequent ladders. Concerning the application itself, the participants gave positive feedback, even though some of them did not feel satisfied because they became tired. Convenience, objectivity, disinhibition, easy scheduling and flexibility were identified. The viability of online in-depth interviewing via real-time chats was confirmed, raising the question of the possibility of it achieving other qualitative research techniques.
\end{abstract}

Key words: qualitative research; laddering technique; online via chat interviewing; consumption experience of caipirinha. 


\section{Introduction}

The use of qualitative methods has gradually been intensified by marketing researchers. As Malhotra (2006, p. 156) noted, there are several reasons for doing qualitative research; "values, emotions and motivations situated in the subconscious level are covered to the exterior world by rationalization ... In these cases, the best way to obtain the desired information is through qualitative research".

One of the main means of qualitative data collecting is the in-depth interview and, among its techniques, the one that has most attracted the attention of researchers in recent years is laddering which, based on the Means-End Theory, presents a "questioning line that goes from the features of the products to the consumer's features. The laddering technique offers a way to investigate consumers' profound and underlying psychological and emotional motivations that affect their buying decisions" (Malhotra, 2006, p. 164).

The leading actor of this scenario, is the Marketing Science Institute's so called connected customer in its guide Research Priorities 2006-2008, which described research topics identified by the institute's corporate sponsors as those that most require academic study. Today's consumers are increasingly connected to their suppliers and competitors, to each other and to third-party information providers. That is why it is said that the connected customer's era can change the paradigm of the effective marketing strategy (Marketing Science Institute [MSI], 2007). Thus, some topics emerge from this new era; among them there the connection of innovation with growth, to which, "at the development level, customer insights are needed to drive innovation and product and service design" (p. 3), and the connection of customers with companies, emphasizing that "companies are interested in discovering new ways to create and sustain emotional connections with the brand" (p. 4).

In the group of items that deserve considerable attention, according to the Institute, there are the marketing research tools and the following sub-items (p. 7): the role of social networks in consumer decision making; cognitive science applications for marketing research; prediction markets as alternatives to traditional marketing research. Two other sub-items are counted as the most distinct ones for this study: the use of virtual worlds and Internet-based marketing research. This is because the connection the Institute writes about is intensified, if not given, by the Internet that thus becomes a fundamental element for this study development.

In communion with the exposed context, authors such as Mann and Stewart (2004) indicated that conducting qualitative research via the Internet remains a relatively unexplored action. According to Comley (2002), researchers have been accepting online qualitative studies at an easily noticeable slower pace than quantitative online studies. According to Parasuraman and Zinkhan (2002), qualitative research (focus group and in-depth interview) conducted via Internet is a methodological area that deserves a systematic study. For these authors, the Internet facilitates the conduction of qualitative research in a more convenient and effective way than when the same research is carried out through conventional means. Moreover, Primo (2001) emphasizes that chats offer an environment for real-time free discussion which can be used in qualitative research. He notes that through chats "interagents get changed by one another while building a relation; they debate diverse subjects at a speed similar to a face-to-face dialogue" (p. 10). It can therefore be observed that there is a positive interaction between the chat participants.

As customers become increasingly connected to the internet, they are more available to be interviewed online. This means that a new space is available for investigating research methods, especially qualitative ones, in an attempt to identify how to adapt data collecting instruments to this new scenario. In this context, the focus of this article is to analyze the viability of applying the laddering technique used online and in real-time chat. Although there are papers that have dealt with the laddering technique in a web-based format using the exchange of e-mail messages (Ribas \& Lima, 
2008), no previous account of web-based chat interviewing has been found in the literature. To aid in this analysis, the following question was asked: What is the value of the consumption experience of caipirinha using the web-based laddering technique via chat?

The answer to this question was helpful in achieving the aims of this article. The consumption experience of caipirinha was chosen as the object of analysis based on its characteristics. As it constitutes a symbol of Brazilian national identity, it strengthens the reach of means-end chains as a whole.

Having become part of the national identity, caipirinhas are present in almost every Brazilian social act and are very well accepted by foreign tourists. In 2003, the Brazilian government issued a decree (n. 4.851) in order to guarantee the intellectual property of the names Cachaça (a distilled drink made from sugar cane) and Caipirinha (Decreto n. 4.851, 2003). The fame of the caipirinha is echoed internationally. In Germany, for example, the drink is in first place among cocktails made with distilled liquors. Caipirinha thus has an important role in the girl publicity (it is a feminine noun in Portuguese) of cachaça abroad. When inserted into this scenario, the consumption experience of caipirinha as the object of analysis becomes considerably attractive.

This article is divided into six parts: the following section presents the theoretical basis for the study. In the first section, the methodological proceedings are exposed. The second section of the article contains data analysis and in third section the results are discussed. In final section the considerations are given.

\section{Theoretical Basis}

In order to analyze the online laddering technique via chat in an objective manner, it is necessary to comprehend the technique in its traditional context, including the vision of value to the customer, a fundamental assumption in the use of this technique. The related literature is reviewed is this section, constituting the basis of this study and its empirical investigation.

\section{Value to the customer}

Value to the customer is one of the marketing constructs that better approaches the attempt to grasp the customer's preferences. The term value presents a broad concept, arising from several fields of knowledge such as Economics, Business Administration, Psychology, Sociology and Ethics, among others. Rokeach (1973) presented a socio-psychological approach to the concept, in which values are related to end states of life (the objectives and targets we live for). He separates values into terminal values, such as freedom, safety, pleasure, happiness, and instrumental values (connected with behavioral standards), for example, happy, courageous, independent, accountable, generous. In this perspective, value is defined as a belief that some ways of behaving are socially or personally preferable to an opposite situation (Rokeach, 1973). Table 1 presents both the instrumental (modes of conduct) and terminal values (end states) proposed by Rokeach.

\section{Table 1}

Rokeach's Research Instrument on Values

\begin{tabular}{ll}
\hline Terminal Values & Instrumental Values \\
\hline A comfortable life & Ambitious \\
An exciting life & Broad-minded \\
World at peace & Capable \\
\hline
\end{tabular}


Table 1 (continued)

\begin{tabular}{ll}
\hline Terminal Values & Instrumental Values \\
\hline Equality & Cheerful \\
Freedom & Clean \\
Happiness & Courageous \\
National security & Forgiving \\
Pleasure & Helpful \\
Salvation & Honest \\
Social recognition & Imaginative \\
True friendship & Independent \\
Wisdom & Intellectual \\
A world of beauty & Logical \\
Family security & Loving \\
Mature Love & Obedient \\
Self-respect & Polite \\
Sense of accomplishment & Responsible \\
Inner harmony & Self-controlled \\
\hline
\end{tabular}

Note. Source: Rokeach, M. (1973). The nature of human values (pp. 355-361). New York: The Free Press; Sheth, J., Mittal, B., \& Newman, B. (2001). Comportamento do cliente: indo além do comportamento do consumidor (p. 345). São Paulo: Atlas.

Since the 1980s, the concept of value to the customer has been increasingly considered in the literature on marketing and consumer behavior (Silveira, 2003), in which this approach goes beyond the mere economic factors, as they seem insufficient for comprehending the reasons why an individual acquires or uses a certain product (Ikeda \& Veludo-de-Oliveira, 2004). According to Flores (2007), viewing the approach from all the definitions of value demonstrates some aspects of consensus and some aspects of differences in the bases for its understanding. For Zeithaml (1988), perceived value is the general assessment made by the customer of the utility of a product based on his/her perceptions of what is received and what is given.

Holbrook (1999) emphasized that value constitutes an interactive relative preference experience concerning the evaluation of an object by an individual. This author says value can exist in a consumption experience, i.e., value lies not in the acquired object or in the chosen brand but in the experience derived from them.

Woodruff (1997) suggested a hierarchy where the customer's desired value is composed of preferences for specific and measurable dimensions (so called attributes). The performance of these attributes and its consequences are linked to the objectives of the product-use situation. Consequences are situated in the intermediate level of the hierarchy and can comprise positive or negative considerations. Finally, values are at the upper level and can be characterized as a customer's personal values, which motivate him to use a certain good or service.

\section{Means-end chains and the laddering technique}

The Means-End Chains Theory pays special attention to understanding consumer behavior and perceived values related to the attributes of goods and services (Gutman, 1982). According to Veludode-Oliveira and Campomar (2006), the Means-End Chain theory presents a value hierarchy, in which 
it is possible to sequentially link attributes (characteristics of the product), consequences (psychological and physiological aspects of the reason why a product is important) and values (a person's main objectives in life) producing a chain - or ladder - of means and ends.

The origin of the theory is explained by Gutman (1982): means are objects (products) or activities people engage in, while ends are valued end states, such as happiness, security and sense of accomplishment. So the core of the theory lies in customers' choice of actions that produce desirable consequences and minimize undesirable ones. The act of consumption is an opportunity for customers to obtain desirable consequences, derived from the individual's values. As Ikeda and Veludo-deOliveira (2004) remarked, the attributes of the product are the means to reach an end, a value.

Ikeda and Veludo-de-Oliveira (2004) stated that the laddering technique emerged as a tool for trying to understand the meaning of certain behaviors and has been used in marketing and management to investigate an individual's opinions, attitudes and beliefs. It has been recommended in research that deals with value to the customer according to the Means-End Chains Theory. The laddering technique is intended to access the individuals' personal system of meanings. It is an essentially qualitative technique that demands abstractions from respondents.

Reynolds and Gutman (1988) defined laddering as an in-depth individual interviewing technique, used to comprehend how customers translate the attributes of products into associations with meanings related to themselves, in a Means-End Chains Theory mode.

Figure 1 shows a complete means-end chain - a ladder - on wine consumption. Originally exposed in Reynolds and Gutman (1988), it is composed of one attribute, two consequences and one value, and represents to customers that less alcohol avoids drunkenness, helping in socialization processes and, finally, bringing to customers a sense of belonging to the group.

\section{Table 2}

Example of Laddering on Wine Consumption

\begin{tabular}{ll}
\hline Value & Sense of belonging \\
Consequence 2 & Helps in socialization \\
Consequence 1 & Avoids drunkenness \\
Attribute & Less alcohol \\
\hline
\end{tabular}

Note. Source: Adapted from Reynolds, T., \& Gutman, J. (1988). Laddering, theory, method, analysis, and interpretation (p. 16). Journal of Advertising Research, 28(1), 11-31.

Another perspective comes from Young and Feigin (1975), where chains are composed of benefits - functional, practical and emotional - linked to the attributes of the product. An interpretation for the consumption experience of caipirinha can be made (Table 3) for a better understanding of this perspective.

Table 3

Example of Young and Feigin's Benefits Chains Model applied to caipirinha consumption

\begin{tabular}{lllll}
\hline Product & $\begin{array}{l}\text { Attribute of the } \\
\text { product }\end{array}$ & Functional benefit & Practical benefits & Emotional benefits \\
\hline Caipirinha & $\begin{array}{l}\text { Fresh limes, cachaça, } \\
\text { ice and sugar, all } \\
\text { together }\end{array}$ & A better taste & $\begin{array}{l}\text { I I enjoy the liquor } \\
\text { I I get cheerful }\end{array}$ & $\begin{array}{c}\text { ・ I have more } \\
\text { pleasure drinking } \\
\text { I I feel happiness }\end{array}$ \\
\hline
\end{tabular}

Note. Source: Present Study. 
In the sequence above, the indication of elements related to caipirinha begins with an attribute of the product that produces benefits ranging from functional to emotional, i.e., all elements are connected in cause-effect terms, making the laddering analysis possible.

\section{The laddering analysis}

For Reynolds and Gutman (1988), the laddering analysis is the most traditional method of obtaining means-end chains. In addition to guiding primary data collection, the laddering also involves procedures for data analysis and interpretation. The laddering interview depends essentially on the interviewees' answers in order to go further, and the question Why is it important? is used as a point of reference.

The steps involved in this method can be taken from Reynolds and Gutman (1988) and Gengler, Klenosky and Mulvey (1995) and summarized as follows:

- Data conversion into separated sentences, followed by identification of the elements that better represent concepts mentioned by each respondent individually;

. Content analysis of the selected elements;

- Development of a set of codes that summarize concepts with similar meanings, which results in a quantitative evaluation of all the pair wise associations, so-called implications;

. Representation of the main implications in a diagram, the Hierarchical Value Map (HVM).

Ikeda and Veludo-de-Oliveira (2004) reported that the laddering technique is carried out through personal and individual in-depth interviews, in which the interviewee's behavior is abstracted in a way that allows the identification of existing links among attributes, consequences and values. In a laddering interview, respondents are encouraged by repeated and interactive questions to further the discussion on the attributes, gradually indicating consequences and personal values. The researcher leads the respondent to abstraction by questioning why a certain attribute (or consequence) is important. Questions such as Why is that important?; What does that mean to you? and What is the meaning of this product that lends (or does not lend it) this attribute? are repetitively asked with the intention of forcing respondents to express consequences derived from attributes and personal values raised by these consequences (Ikeda \& Veludo-de-Oliveira, 2004).

The analysis process begins with a careful reading of data in a search for parts of the text that reflect the core aspects of the interview. For each part of the text a representative sentence is identified; citations with the same meaning are grouped together and considered a single sentence. After dismembering the rough data, their elements are categorized into attributes, consequences and personal values, resulting in a collection of elements (key words) related in an A-C-V sequence which briefly express the individuals' reasoning. In the end, there are many A-C-V sequences. It is important to emphasize that it is not always possible to obtain means-end chains from all the interviews. Reynolds and Gutman (1988) argued that it is usual that up to one fourth of the total number of interviews do not develop ladders. On average, it is possible to identify from 2 to $3 \mathrm{~A}-\mathrm{C}-\mathrm{V}$ sequences from $75 \%$ of the respondents (Dibley \& Baker, 2001; Reynolds \& Gutman, 1988).

Next, the identified elements are codified by numbering them, starting from the elements at the lowest level of the chain (attributes). According to Reynolds (1995), content analysis is an interactive task in which the analyst can codify data and combine, separate, eliminate or create new categories till (s)he feels an optimal solution was reached. The end result is summarized in a table containing the main elements gleaned from the interviews, categorized and codified in the value hierarchy.

The construction of the implication matrix is the subsequent stage. All elements selected in the previous steps are allocated into the lines and columns of a numerical table considering their codes. A matrix is formed by counting the number of times elements lead to each other (on a ladder, which element precedes another) and differently representing the type of relation between elements (direct 
relations of adjacent elements appear to the left of the decimal point and indirect relations to the right). It is necessary to analyze all the ladders obtained in order to classify and count the existing relations (Ikeda \& Veludo-de-Oliveira, 2004).

The proposal of this method to graphically represent the obtained chains in the Hierarchical Value Map (HVM), which provides an easier interpretation of a group of consumers' values and the recognition of the strongest and more relevant relations and chains for understanding the phenomenon (Reynolds \& Gutman, 1988).

\section{Methodological Proceedings}

For the purpose of verifying the application viability of the laddering technique used online via chat, data collection was carried out in real time, in a virtual environment and in a written mode through instant messages sending software. Online tools have been called "the fourth revolution in communication and the production of knowledge" (Harnard as cited in Mann \& Stewart, 2004, p. 3), for providing qualitative researchers with attractive opportunities.

It is, perhaps, surprising that the suitability of the Internet for conducting research remains relatively unexplored. While there have been some early initiatives in a quantitative research setting, there has been little systematic analysis of how the Internet might be incorporated into qualitative research practices (Mann \& Stewart, 2004, p. 4).

In this sense, the authors note that qualitative researchers that utilize computer mediated communication have been proceeding with few practical or theoretical guidelines. This factor was a determinant of this study's production initiative.

\section{Sampling proceeding}

This study counted on a non-probabilistic convenience sample for its easier operational implementation and low variation in population (Malhotra, 2006). According to Malhotra (2006), convenience samples can be used in exploratory research to generate ideas, intuitions and hypotheses. Homogeneity is of great importance in this study because the more uniform the sample, the lower the probability of intervenient or strange variables to influence the end results.

The sample was composed of Master's Degree and $\mathrm{PhD}$ students from a Brazilian university. The interviewees had the following features in common: they were aged 20 to 45, were consumers of caipirinha (and/or its variations), having drunk it within the four months prior to the interview (in order to make it easier for respondents to remember situations) and they all had access to Messenger (MSN) - instant messages sending software that can be freely downloaded on the Internet - and/or Skype, a transmission technology tool for delivery of voice communications over the Internet (VOIP).

The population was carefully selected in order to make sure that the subjects were already familiar with online environments and were skilled typists, since many Brazilians have no access to the Internet and have no knowledge or skills when it comes to using communication tools via the web. Both Microsoft's Messenger MSN and Skype are the most utilized tools in Brazil with 30.5 and 3.8 million users, respectively (Felitti, 2007).

To ensure that the respondents would take part in the study, a caipirinha kit was raffled among the interviewees, containing the ingredients and an apparatus for preparing the popular version of the liquor (limes, sugar, cachaça, a pestle, a glass, a chopping board and a knife) at the end of the interviewing phase. 


\section{Data collection}

Data collection was based on the laddering technique using individual semi-structured in-depth interview in the online chat mode. The interview script was tested by carrying out 2 interviews through Messenger (MSN), which resulted in improvements to the script, especially concerning particular characteristics of the object of study: the consumption experience of caipirinha. All interviews were in Portuguese and conducted by the authors of this paper.

It was a three-part script. The first part was intended to make sure the interviewee really matched the description given above in subsection Sampling Proceeding. Part 2 contained a series of semi-structured questions on the consumption experience of caipirinha. The last part served to check both the interviewers' and the respondents' satisfaction with the applied format (via online chat). Interviewers also had to note how long the interview took. It was already known that transcription wouldn't be necessary since the chosen web tools make it possible to copy and paste the whole conversation in a Word for Windows file.

The data collection itself took place between November $20^{\text {th }}$ and December $17^{\text {th }}, 2007$. The confidentiality of the data was guaranteed and lent more weight to the academic purpose of this study in all interviews.

\section{Results}

Data analysis and interpretation were conducted as indicated by Reynolds and Gutman (1988). It is important to note that the laddering technique formed the data collection, codification and categorization model and also a results presentation mode in this study. No specific software was used; data analysis was conducted manually, since a tool adapted to Internet-based interviewing and to its typical language was unknown to the authors of this article.

The following subsections present the profile of the interviewed sample, demonstrate the steps taken to analyze and interpret the detected ladders. The participants' perceptions of the application of the web-based chat format are given in the sections.

\section{Sample's characteristics}

Ten individuals were interviewed. Although there are suggestions in the literature as to how many respondents to question in a quantitative measurement of means-end chains, i.e., approximately 30 (Hofstede, Audernaert, Steenkamp, \& Wedel, 1998), the decision to use 10 was reached after achieving the theoretical saturation of responses allied to the identification of repeated and complete A-C-V chains, enabling an analysis of the viability of the application in the tested format (web-based chat laddering), the focus of this article.

The average age of the sample population was 26 . Women made up $40 \%$ of the sample, while men accounted for 60\%; $90 \%$ of the respondents are Master's Degree students and only $10 \%$ studying for a $\mathrm{PhD}$. Concerning internet communication tools, $90 \%$ of the individuals were interviewed using Messenger (MSN) and 10\% using Skype. Both of the tools are frequently utilized by the whole sample. The average data collection time was 58 minutes.

\section{Data analysis and interpretation}

For content analysis, each researcher carefully analyzed one by one the transcription of all interviews (s)he conducted in search of components of the chain. Afterwards, all the authors together created a consolidation chart in which each one of the elements with a similar meaning is detected and codified (example: Integration $=$ Social interaction). In total 23 attributes, 22 consequences and 13 
values were identified. Tables 4,5 and 6 show examples of the categorization and codification of values, consequences and attributes respectively.

Table 4

Examples of Categorization and Codification of Detected VALUES

\begin{tabular}{lll}
\hline Code & Category & Description \\
\hline 46 & True friendship & $\begin{array}{l}\text { Our friendship grew stronger/ Joy of having dear friends around you that moment } \\
\text { / Friendship/ It brings friends together }\end{array}$ \\
49 & Happiness & $\begin{array}{l}\text { Possibility of being really happy, without any sign of sadness/ That we always } \\
\text { keep ourselves delighted and happy / Sense of constant happiness } \\
\text { Pleasure (to make the most of life pleasure) / Thoughts that this moment is worth } \\
\text { having / Feeling good 'cause it makes pleasure complete / Pleasure for my taste }\end{array}$ \\
\hline
\end{tabular}

Table 5

\section{Examples of Categorization and Codification of Detected CONSEQUENCES}

\begin{tabular}{lll}
\hline Code & Category & Description \\
\hline 25 & Pleasing to the taste & $\begin{array}{l}\text { I like the taste of the liquor/ Satisfaction of having a drink / Appreciate its } \\
\text { taste/ Because it is better for my taste/ Tasty }\end{array}$ \\
32 & Entertainment & $\begin{array}{l}\text { To get entertained/ Not feeling upset/ Even more entertained/ It makes people } \\
\text { set themselves free }\end{array}$ \\
34 & $\begin{array}{l}\text { Insouciance/ } \\
\text { relaxation }\end{array}$ & $\begin{array}{l}\text { Insouciance/ Relaxing moment/ Not feeling worried/ You forget about your } \\
\text { problems and about stress / Having no worries/ The place is not stressful } \\
\text { To integrate the group/ It makes living together easier/ To fraternize/ } \\
\text { Membership/ To interact/ It is a socially favorable situation }\end{array}$ \\
\hline
\end{tabular}

Table 6

\section{Examples of Categorization and Codification of Detected ATTRIBUTES}

\begin{tabular}{lll}
\hline Code & Category & Description \\
\hline 01 & Alcohol & $\begin{array}{l}\text { Caipirinha (alcohol)/ Alcoholic beverage/ Alcohol Content/ Alcohol/ It is } \\
\text { a strong drink }\end{array}$ \\
06 & Heat/ summer & $\begin{array}{l}\text { Hot weather/ Summer/ Heat/ Sun/ Hot seasons/ Spring/ On a hot summer } \\
\text { day/ The weather (a hot day) } \\
\text { Drinking caipirinha with friends/ Mates/ Friends meeting/ To be with } \\
\text { your friends/ Having the company of friends is fundamental for } \\
\text { caipirinha/ It is a liquor to be drunk with friends } \\
\text { Party/ Bar/ At a night club/ Carnival/ Slumber parties/ Pubs/ Celebrating } \\
\text { moments / Public holidays/ Christmas and New Year's Eve }\end{array}$ \\
\hline
\end{tabular}

With the categorization and codification done, the data were compiled and validated by the interviewers. For each interview, a table of ladders and the implication matrix were built. Data analysis resulted in 133 ladders identified, of which 71 reached the value level. An average of 14 ladders was found for each respondent and citation of elements varied from 2 to 11. Examples from the table of ladders are shown below. 
Table 7

Excerpt from the Table of Ladders

\begin{tabular}{|c|c|c|c|c|c|}
\hline \multirow{2}{*}{$\begin{array}{l}\text { Ladder } \\
\text { number }\end{array}$} & \multirow{2}{*}{$\begin{array}{l}\begin{array}{l}\text { Interviewee } \\
\text { Number }\end{array} \\
05\end{array}$} & \multicolumn{4}{|c|}{ Element code } \\
\hline & & 16 & 25 & & 52 \\
\hline 66 & 05 & 08 & 27 & 28 & 46 \\
\hline
\end{tabular}

The respondents evoked not only concrete attributes of caipirinha but also aspects concerning the consumption experience, such as physical environment, climate and even cultural matters, showing that much more than just a drink or a product, caipirinha reminds the respondents of the whole experience itself. Figure 1 below displays the most important relations in terms of how frequently they were mentioned.

\begin{tabular}{|c|c|c|}
\hline $\begin{array}{l}\text { Insouciance/ } \\
\text { relaxation }(\mathbf{C})\end{array}$ & $\rightarrow$ & Pleasure (V) \\
\hline Alcohol (A) & $\rightarrow$ & Disinhibition (C) \\
\hline $\begin{array}{l}\text { With friends /mates } \\
\text { (A) }\end{array}$ & $\rightarrow$ & Fun $(\mathbf{V})$ \\
\hline
\end{tabular}

Figure 1. Most Mentioned Relations

Logical and complete ladders (A-C-V chains) were detected, proving the viability of web-based chat interviewing. The most frequent ladders are those shown in Figure 2 below.

\section{- With friends/ mates (and also Company) $\rightarrow$ Integration $\rightarrow$ Entertainment $\rightarrow$ Fun}

- Alcohol $\rightarrow$ Insouciance/ relaxation $\rightarrow$ Pleasure

Figure 2. Most Frequent Ladders

All the values mentioned except Self-Esteem and Sense of Accomplishment are related to company (friends/ mates or family). The values Happiness and Social Recognition also result from Company, given that they are indirectly linked by the consequences Integration and Good Moments. It is interesting that Sense of Accomplishment derives from elements related to concrete attributes, particularly referring to ingredients and flavor.

A Hierarchical Value Map was constructed considering all direct and indirect relations. The HVM is supposed to significantly represent the main implications (Reynolds, 1995). The implication matrix was crucial for the construction of the map because the most frequent relations (not ladders) could easily be identified, and two thirds $(67 \%)$ - as suggested in the literature - of all existing relations were covered by the HVM (Appendix).

\section{Participants' perceptions of the application}

Researchers considered the scheduling of the interviews easy and quick, as there was no need to come to a definition as to where the conversation would take place: asking the respondent the communication web tool (s)he uses and her/his web contact/ address was enough. Thus, without great moves, defining the date and time was made easier as long as the respondent had access to a computer connected to the Internet.

The interviewees expressed satisfaction with the web-based chat technique. Some of them praised the innovative approach of this study ("...the subject... using technology (this Internetmediation), which I find really valid, really up-to-date..."; "I liked it, yeah! First, because it's unusual 
to use MSN for this"). On the other hand, although satisfied, some respondents said they became tired ("...sometimes the connection between the questions... became tiring...", "Nice, but tiring").

At the end of each chat, the interviewers had to register their perceptions. Their satisfaction was not unanimous. The main complaint was the tiredness due to the long period conducting the chat. Moreover, they criticized the possibility that the respondents could become distracted, i.e., lose their concentration and change focus while being interviewed.

Three positive qualities were pointed out by the interviewees when discussing why they liked the online format:

- Convenience: if it had been a face-to-face interview, a respondent said that the schedule would not have been the most suitable one for him, indicating that the main advantage of the online format was indeed convenience.

. Objectivity: when you have to type, you try to say the main things; I guess I would have said a million things during a F2F conversation... I'm a little distracted, like this, it was great for the two of us... I was objective, but I sent the same message (that I would if it were a F2F interview).

. Disinhibition: maybe a voice recorder would restrain a little ...; we listen to the other person when we're typing .

According to the interviewers, online chats had some advantages, such as easy scheduling, the possibility of performing other tasks at the same time, good location (participants do not need to be in the same place/town/city/country) and objective answers.

Participants' satisfaction and average time are shown in Table 8 below.

\section{Table 8}

Participants' Satisfaction and Average Time of Application

\begin{tabular}{lll}
\hline Variables & Measures & Online format \\
\hline Average data collection time & Average time (minutes) & $58 \mathrm{~min}$ \\
Average transcription time (or copy to Word and adjustments) & Average time (minutes) & $2 \mathrm{~min}$ \\
Total average time & Average time (minutes) & $60 \mathrm{~min}$ \\
Satisfied respondents with the format & Categorical answers & $100 \%$ \\
Satisfied interviewers with the format & Categorical answers & $70 \%$ \\
\hline
\end{tabular}

Concerning the perceptions of the participants, Table 9 shows their main remarks.

\section{Table 9}

Respondents' and Interviewers' Perceptions

\begin{tabular}{ll}
\hline Participants & Perceptions \\
\hline Respondents & . Convenience \\
& . Objectivity \\
& . Disinhibition \\
Interviewers & . Easy scheduling \\
& . Location \\
& . Objectivity \\
& . Flexibility \\
\hline
\end{tabular}


. Possibility of performing other tasks at the same time

Both interviewers and respondents referred to objectivity. Short answers were given by respondents after a previous consideration, revealed by time lags between questions and answers. This objectivity does not mean superficiality given that complete ladders (A-C-V) were achieved and a coherent and understandable HVM could be built.

\section{Discussion}

Freitas, Janissek-Muniz, Baulac and Moscarola (2006) explained that online discussions, such as chats, efficiently support qualitative research in a virtual environment. The level of interaction with the respondent is enhanced and opens the way for multidirectional dialogues capable of generating important qualitative data reports, which was confirmed in this study.

Some aspects become clearer in the context of application of this qualitative research via chat. Positive qualities stand out in this format: there is an immediate access to the written interviews in their entirety, with no need to transcribe them as usually done in the case of voice-recorded, resulting in time optimization as well as less expenditure on resources for recording and transcription. Regarding MSN Messenger and Skype, they are both freely accessed on the Internet and therefore do not incur software license costs. Basically, interviewing requires access to the Internet, preferably broad band Internet by respondents and interviewers. This was a requirement for the student to be included in the sample, enabling the use of a zero-cost data collection instrument given the already existing expenses in broad band Internet before the execution of this research.

Another advantage has to do with when and where the interviews can take place: all of them were scheduled at the respondents' convenience. The mobility offered by the Internet permitted interviews to be conducted at different times and in different places, outside of business hours, on weekends and during trips. Therefore, the online data collection, even in real time, could be carried out irrespective of the respondents' and interviewers' location. This reduced the time spent moving to the place of interview and also the need to adjust the participants' face-to-face attendance, since they must be available at the same time in a pre-arranged virtual space but not in the same location. The fact that it was easy and quick for respondents to schedule and to choose the most convenient and comfortable location gave them much greater freedom to speak out. This may have helped the researchers to obtain better results.

The communication tools used online allowed the researchers to save the interviews as digital files during the chats, in which the whole conversation could be checked out whenever the interviewers wished to remember a respondent's previous answers in order to better explore her/his perceptions by formulating more appropriate and effective questions. The respondents themselves could also go over the conversation text and reaffirm (or not) their answers later in the interview. Moreover, in possession of the semi-structured interview script file saved in their computers, the researchers could copy and paste some of the questions according to the progress and course of the answers and to the attainment of ladders, making the interview easier and more agile.

Among the negative aspects, the long interview time attracts attention, as the online chat requires both participants' dedication, reading and typing. Interruptions may occur while collecting data due to external factors like interference by family members, visitors and phone calls, since individuals can participate in the chat from their homes or workplaces. Mann and Stewart (2004) see interruptions as an advantage because the interviewee does not need to stop her/his daily life. However, it is not possible to be sure that the respondent is giving his full attention to the interview. There are also concerns about his/her line of argumentation. Furthermore, technical problems such as a failed or low-speed connection may occur and restrict the interviewing process. In fact, one interview 
was interrupted for some minutes by a connection failure. However, after the problem was solved the participants were able to continue their chat.

The interviewers missed body language and tone of voice and felt limited by written communication. A reason for discomfort had to do with hesitation in choosing the most appropriate moment to move on to the next question of the interview script. Quite often it was difficult to identify the right moment to cut in on the respondent, i.e., to be sure that (s)he had concluded her/his line of argumentation.

Despite being an outstanding aspect, the language used in the interviews could not be classified as positive or negative. Online discourse is known for containing non-verbal and extralinguistic behavior exhibited in emoticons and cues such as electronic paralanguage - e.g., expressiveness, multiple vowels and multiple punctuation marks - which help to reinforce answers, opinions and feelings. Shortened words are also very usual in online discourse to reduce time spent typing. All of these items together with typing mistakes were observed during data collection and none of them weaken or directly interfere in the results found in this study.

\section{Final Remarks}

The need to exploit the potential and applicability of new web-born technologies in the context of the connected customer was what triggered this research.

The study identified that the laddering technique can be extended as a practice among marketing researchers through its application via Web, providing they choose objects of study and sample profiles appropriate to the peculiarities of the virtual environment. Based on the MEC Theory and on the laddering technique, this research focused on promoting the possibility of their adequacy for realtime virtual context and succeeded.

Primo's notes (2001) were strengthened by the results obtained: chats constitute a powerful tool for mutual interaction supported by messaging speed, which was full of intense dialogues between participants in this study in spite of not being physically in touch.

Convenience, objectivity, disinhibition, easy scheduling, location and flexibility were the most frequently perceived qualities, which means that the online format received a good mark, although not all the participants were satisfied, mainly because of tiredness.

\section{Academic and managerial implications}

From the academic point of view, this paper restates the need to investigate the usage of the laddering technique and updates it on the connected customer. In this sense, the study emerges as a contribution to the previously presented scenario, more specifically disclosing the values involved in the consumption experience of caipirinha through online laddering in real time. The results affirm the efficacy of the technique proposed by Reynolds and Gutman (1988) since ladders could be built and an analysis of value was feasible. Moreover, they confirmed the viability of online in-depth interviewing via real-time chats, raising the question about its possibility of reaching into other qualitative research techniques.

Taking into account the fact that Brazilian public higher education institutions have the infrastructure needed (computers connected to the Internet), that many of them lack financial resources, that their academics - most of them post-graduation students - are teaching while people are able to be interviewed and that increasing the number of papers published is a matter of urgency (and, thus, faster research processes are fundamental), data collection in a virtual environment does constitute a very attractive alternative for academia 
Regarding managerial aspects, the online via chat format can facilitate decision making with the improvement of competitive intelligence activities. A dynamic data collection that results in more information is able to encourage companies to do their own research and also to interact with their clients, creating a real network.

Online discussion forums can be consolidated as a research tool for practitioners characterized by low cost, accessibility and nimbleness. In addition, beverage companies can make use of the results obtained in this study and recover the values detected in their promotional strategies, designing them to offer the market an experience in an atmosphere favorable to integrating people. Given that caipirinha is a part of the respondents' social acts, the consumption experience becomes as important as - or even more than - the drink itself.

\section{Limitations and future research}

This study was concentrated in the application mode of the technique and not necessarily in the object in question. Observing the analysis of the consumption experience of caipirinha, it seems it could be expanded in search for generalization of its results by adjusting the sampling procedure, which can guarantee external validity. However, the differentiated profile of the sample was a limitation for this study. Access to the Internet and skill in dealing with chat tools (pre-requisites for carrying out this research) ended up limiting the sample when considering age groups, customs, geographical regions and economic and educational level. Moreover, it is considered a captive sample since it maintains a strong intellectual interest in research methods and in academic activities in general. Despite the low-powered results in terms of extrapolation, they are reasonable and sensible when it comes to qualitative research, in which the understanding of some observations is deepened; large amounts and statistics are not taken into account. In this sense, the sample utilized can be suitably and positively qualified.

A replication of this study is recommended, involving only foreigners and/or Brazilians that live abroad to better understand why caipirinha plays the girl propaganda role of cachaça in other countries and thus increases its exports.

Finally, it would be interesting to add other computational tools in the web-based mode such as microphones or webcams to check whether they contribute to collecting more data from interviewees. New web-born technologies, however, do not substitute conventional techniques (this is certainly not the intention) but there is no doubt that they increase the number of alternatives available to marketing researchers. However, these new tools complement the current methodological arsenal and are instrumental in the drive to understand the connected customer era.

Received 08 October 2009; received in revised form 19 August 2010.

\section{References}

Comley, P. (2002). Online survey techniques: current issues and future trends. Interactive Marketing, 4(2), 156-169. doi:10.1057/palgrave.im.4340174

Decreto n. 4.851, de 2 outubro de 2003. (2003). Altera dispositivos do regulamento aprovado pelo Decreto no 2.314, de 4 de setembro de 1997, que dispõe sobre a padronização, a classificação, o registro, a inspeção, a produção e a fiscalização de bebidas. Brasília, DF: Ministério da Agricultura, Pecuária e Abastecimento.

Dibley, A., \& Baker, S. (2001). Uncovering the links between brand choice and personal values among young British and Spanish girls. Journal of Consumer Behaviour, 1(1), 77-93. doi: $10.1002 / \mathrm{cb} .55$ 
Felitti, G. (2007). Com 30,5 mil de usuários, Brasil se torna maior base do mundo do Messenger. Retrieved August 15, 2007, from http://idgnow.uol.com.br/internet/2007/08/15/idgnoticia.200708-15.6067592039/

Flores, M., Neto (2007). O valor para o cliente na educação superior (Dissertação de mestrado). Universidade do Vale do Rio dos Sinos, São Leopoldo, RS, Brazil.

Freitas, H., Janissek-Muniz, R., Baulac, Y., \& Moscarola, J. (2006). Pesquisa via Web: reinventando o papel e a idéia da pesquisa. Canoas: Sphinx.

Gengler, C. E., Klenosky, D. B., \& Mulvey, M. S. (1995). Improving the graphic representation of means-end results. International Journal of Research in Marketing, 12(3), 245-256. doi:10.1016/0167-8116(95)00024-V

Gutman, J. (1982). A means-end chain model based on consumer categorization processes. Journal of Marketing, 46(2), 60-72.

Hofstede, F., Audernaert, A., Steenkamp, J. E., \& Wedel, M. (1998). An investigation into the association pattern technique as a quantitative approach to measuring means-end chains. International Journal of Research in Marketing, 15(1), 37-50. doi:10.1016/S01678116(97)00029-3

Holbrook, M. B. (1999). Consumer value: a framework for analysis and research. New York: Routledge.

Ikeda, A. A., \& Veludo-de-Oliveira, T. M. (2004). Uso e limitações do método laddering. Revista de Administração Mackenzie, 5(1), 197-222.

Malhotra, N. (2006). Pesquisa de marketing: uma orientação aplicada. Porto Alegre: Bookman.

Mann, C., \& Stewart, F. (2004). Internet communication and qualitative research: a handbook for researching on-line. London: Sage Publications.

Marketing Science Institute. (2007). 2004-2006 research priorities: a guide to msi research programs $\begin{array}{llll}\text { and } \quad \text { procedures. } & \text { Retrieved 2007, }\end{array}$ http://www.riti.org.eg/MBA_Points/Marketing\%20Science\%20Institute\%20\%96\%20Research $\% 20$ Priorities\%202004-2006.htm

Parasuraman, A., \& Zinkhan, G. M. (2002). Marketing to and serving customers through the internet: an overview and research agenda. Journal of the Academy of Marketing Science, 30(4), 286295. doi: $10.1177 / 009207002236906$

Primo, A. (2001). Ferramentas de interação em ambientes educacionais mediados por computador. Educação, XXIV(44), 127-149. Retrieved December 10, 2009, from http://www.nuted.ufrgs.br/oficinas/interacao/ferramentas_interacao.pdf

Reynolds, T. (1995). Laddering: extending the repertory grid methodology to construct attributeconsequence-value hierarchies. Journal of Advertising Research, 35, 155-167.

Reynolds, T., \& Gutman, J. (1988). Laddering, theory, method, analysis, and interpretation. Journal of Advertising Research, 28(1), 11-31.

Ribas, J. R., \& Lima, A. L. S. de (2008, maio). Uma abordagem da técnica laddering no abastecimento de combustível automotive. Encontro de Marketing, Curitiba, PR, Brazil, 3.

Rokeach, M. (1973). The nature of human values. New York: The Free Press. 
Sheth, J., Mittal, B., \& Newman, B. (2001). Comportamento do cliente: indo além do comportamento do consumidor. São Paulo: Atlas.

Silveira, T. da (2003, setembro). A gestão do conhecimento sobre valor para o cliente e a performance organizacional. Encontro Nacional da Associação Nacional de Pós-Graduação e Pesquisa em Administração, Atibaia, SP, Brazil, 27.

Veludo-de-Oliveira, T. M., \& Campomar, A. A. (2006). Laddering in the practice of marketing research: barriers and solutions. Qualitative Market Research, 9(3) 297-306. doi: $10.1108 / 13522750610671707$

Woodruff, R. B. (1997). Customer value: the next source for competitive advantage. Journal of the Academy of Marketing Science, 25(2), 139-153. doi: 10.1007/BF02894350

Young, S., \& Feigin, B. (1975). Using the benefit chain for improved strategy formulation. Journal of Marketing, 39(3), 72-74.

Zeithaml, V. A. (1988). Consumer perceptions of price, quality and value: a means-end model and synthesis of evidence. Journal of Marketing, 52(3), 2-22. 


\section{APPENDIX}

\section{Hierarchical value map}

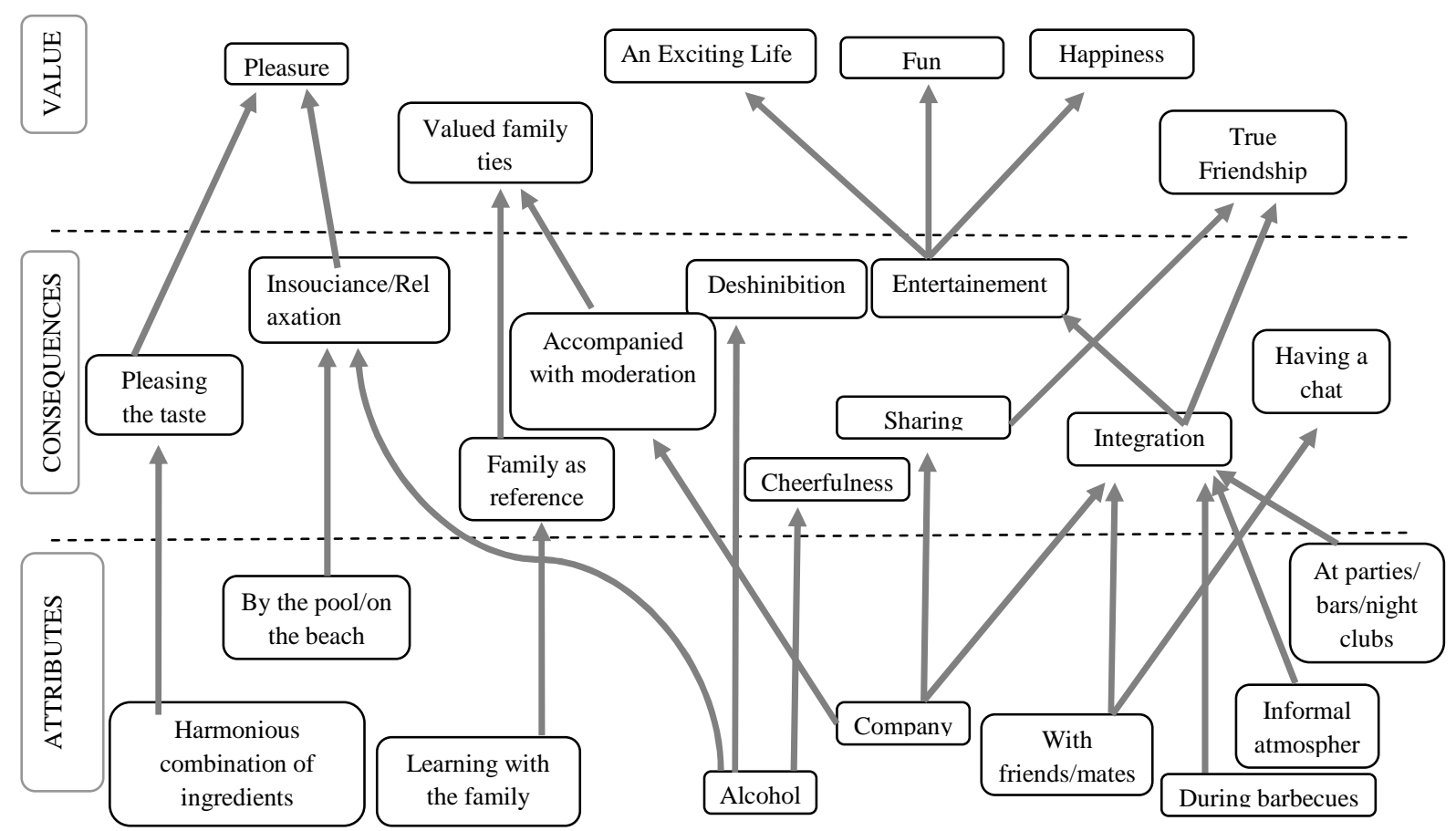

Figure 1. Online Hierarchical Value Map. 